\title{
Psychological Contracts: Back to the Future
}

Citation for published version (APA):

Griep, Y., Cooper, C., Robinson, S., Rousseau, D. M., Hansen, S. D., Tomprou, M., Conway, N., Briner, R., Shapiro, J. A. M., Horgan, R., Lub, X., de Jong, J., Kraak, J. M., O'Donohue, W., Jones, S. K., Vantilborgh, T., Yang, Y., Cassar, V., Akkermans, J., ... Linde, B. J. (2019). Psychological Contracts: Back to the Future. In Y. Griep, \& C. Cooper (Eds.), Handbook of Research on the Psychological Contract at Work (pp. 397-414). Edward Elgar Publishing. New Horizons in Management series https://doi.org/10.4337/9781788115681.00031

Document status and date:

Published: 01/01/2019

DOI:

10.4337/9781788115681.00031

Document Version:

Publisher's PDF, also known as Version of record

Document license:

Taverne

Please check the document version of this publication:

- A submitted manuscript is the version of the article upon submission and before peer-review. There can be important differences between the submitted version and the official published version of record.

People interested in the research are advised to contact the author for the final version of the publication, or visit the DOI to the publisher's website.

- The final author version and the galley proof are versions of the publication after peer review.

- The final published version features the final layout of the paper including the volume, issue and page numbers.

Link to publication

\footnotetext{
General rights rights.

- You may freely distribute the URL identifying the publication in the public portal. please follow below link for the End User Agreement:

www.umlib.nl/taverne-license

Take down policy

If you believe that this document breaches copyright please contact us at:

repository@maastrichtuniversity.nl

providing details and we will investigate your claim.
}

Copyright and moral rights for the publications made accessible in the public portal are retained by the authors and/or other copyright owners and it is a condition of accessing publications that users recognise and abide by the legal requirements associated with these

- Users may download and print one copy of any publication from the public portal for the purpose of private study or research.

- You may not further distribute the material or use it for any profit-making activity or commercial gain

If the publication is distributed under the terms of Article $25 \mathrm{fa}$ of the Dutch Copyright Act, indicated by the "Taverne" license above, 
Full reference: Griep, Y., Cooper, C., Robinson, S., Rousseau, Hansen, S., ..., Linde, B. J. (2019).

Psychological contracts: Back to the future. In Y. Griep \& C. Cooper, Handbook of research on the

psychological contract at work, p. 397-414. Cheltenham, UK: Edward Elgar Publishing.

\section{Psychological contracts: back to the future}

Yannick Griep, Cary Cooper, Sandra Robinson, Denise M. Rousseau, Samantha D. Hansen, Maria Tomprou, Neil Conway, Rob Briner, Jacqueline A-M. Coyle-Shapiro, Robert Horgan, Xander Lub, Jeroen de Jong, Johannes M. Kraak, Wayne O'Donohue, Samantha K. Jones, Tim Vantilborgh, Yang Yang, Vincent Cassar, Jos Akkermans, Denise Jepsen, Chris Woodrow, Simon de Jong, Ultan Sherman, Frank Bezzina, Ceren Erdem, Ann-Marie Nienaber, Philipp Romeike, Sarah Bankins, P. Matthijs Bal, Hermien Wiechers, Leah Pezer, Safâa Achnak, and Barend J. Linde.

\section{SPOTLIGHT ON TIME}

\section{Chronological Time}

Work lives are marked by meetings, schedules, and deadlines, all influenced by the objective passing of 'clock' time (Bluedorn \& Den- hardt, 1988). The dynamic aspects of time (e.g., duration, pattern, sequences) and timing of events shape employee attitudes and behaviors toward the organization (Núñez \& Cooperrider, 2013; Shipp \& Cole, 2015). Despite its ubiquitous nature, issues of time in the workplace, and the temporal nature of employment relationships specifically, remain sorely underresearched, creating a strong need for impactful research on psychological contracts as they are related to time. By acknowledging and incorporating the role of time in theory, we are able to explore the emergence of, or change in, the psychological contract and its antecedents/consequences, the stability (or lack thereof) of psychological contract breach reactions, the rate of change in psychological contract breach reactions over shortand long-term time-lags (e.g., minutes, hours, days, or weeks), and the duration of these effects (e.g., immediate, delayed, or lingering), in both design and analytic approach. Several chapters argued that the psychological contract is a dynamic construct which is formed, maintained, disrupted, and repaired over time (most often with reference to the phasebased model of psychological contracts by Rousseau, Hansen, \& Tomprou, 2018 and the post-violation model by 
Tomprou, Rousseau, \& Hansen, 2015). Moreover, some earlier psychological contract work (e.g., Rousseau \& McLean Parks, 1993; Sels, Janssens, \& Van den Brande, 2004) recognizes that 'time' can be conceptualized as an underlying property of the psychological contract as a whole. Nonetheless, we have limited empirical understanding of the psychological contract as a time-based process (for a few examples, see Conway \& Briner, 2002; Griep \& Vantilborgh, 2018a, 2018b; Ng, Feldman, \& Lam, 2010; Solinger, Hofmans, Bal, \& Jansen, 2016; for a general critique see Hansen \& Griep, 2016). Most empirical work on the psychological contract and its underlying mechanisms has been cross- sectional, and traditional longitudinal studies often failed to consider time-related mechanisms in psychological contract processes (see Roe, 2008 for a critique of traditional longitudinal studies for studying temporal processes). Thus our understanding is based on a snippet of the time frame characterizing the employee-employer relationship, one that most often only focuses on the employee's perspective (for a critique and review of mutuality and reciprocity see Chapter 2 by Schalk and De Ruiter). Concomitantly research designs and analytical methods typically used in contemporary psychological contract research presume linearity (for a few exceptions see Solinger et al., 2016 and several chapters in this book), as represented in associations between psychological contract breach and negative emotional, attitudinal, and behavioral reactions (for meta-analyses see Bal, De Lange, Jansen, \& van der Velde, 2008; Zhao, Wayne, Glibkowski, \& Bravo, 2007).

The historically narrow and simplistic approach to studying the relationships between psychological contract breach, violation feelings, and employee reactions is problematic for multiple reasons. First, emotions, attitudes, and behaviors are interrelated and potentially intensify each other over time (e.g., Beal, Weiss, Barros, \& MacDermid, 2005; Mitchell \& James, 2001). Thus, capturing only current associations impedes our understanding of how interpretations and responses to the psychological contract are formed, maintained, disrupted, and repaired over time. Second, by ignoring the temporal context of psychological contract breach, violation feelings, and employee reactions, we fail to account for how psychological contract phases (initial formation, ongoing mainten- ance, post-violation adjustment) influence how employees experience organizational events and perceived psychological contract breaches and the resulting emotions, attitudes, and behaviors (for a general critique, see Kozlowski, 2009). Failure to account for phases and related temporal context is grounded in the false assumption that employees react in exactly the same way and with the same intensity to events and cues that give rise to psychological contract breach regardless of context. This 
simplistic depiction of reality ignores how perceptions of psychological contract breach are situated in time and in relation to past perceptions (e.g., the history of the employee-employer relationship or previous employment relationships; Griep \& Vantilborgh, 2018b; Sherman \& Morley, 2015) and future expectations of breach (Rousseau et al., 2018). Finally, it is widely assumed that relationships among relevant variables are static, meaning that a given variable holds the same relationship with the psychological contract over time (for an elaborate critique see Hansen \& Griep, 2016). We note that an important predictor at one point in time may, in fact, be an important consequence at another. This static 'antecedentconsequence' way of thinking ignores the conceptualization of psychological contract as a dynamic construct where the role and relevance of variables may change depending on the phase the relationship is in (see the phase-based model of psychological contracts by Rousseau et al., 2018). For instance, promises may not matter to an employee who has settled into a comfortable and predictable period of exchange with the employer, whereas they might matter a great deal to an employee who has just experienced a significant psychological contract breach and is working to repair the employment relationship (see Montes \& Zweig, 2009), underscoring the importance of salience of promises and obligations in the psychological contracting process. Moreover, as employees move through their careers (e.g., receiving more responsibilities) and family situation (e.g., having children), other promises or obligations may become more salient in line with new career or life roles. These criticisms indicate that time plays a critical role in shaping individuals' experiences in organizations. Several chapters (see Chapter 10 by Tomprou and Bankins; Chapter 12 by Achnak and Hansen; Chapter 13 by Rigotti and de Jong; Chapter 14 by Wiechers, Coyle-Shapiro, Lub, and ten Have) have already referred to the recent theoretical advance- ments in psychological contract theory (the phase-based model of psychological contracts by Rousseau et al., 2018 and/or the post-violation model by Tomprou et al., 2015) and have proposed new and exciting methodological advancements (see Chapter 15 by Weinhardt, Griep, and Sosnowska; Chapter 16 by Vantilborgh; Chapter 17 by Hofmans and Vantilborgh; Chapter 18 by de Jong and Rigotti; Chapter 19 by Bankins) to recognize that different psychological contract processes operate at distinct times and unfold at various speeds over the duration of the employment relationship. These recent theoretical developments (Rous- seau et al., 2018; Tomprou et al., 2015) and the numerous chapters in this book have paved the way for exciting new research opportunities. In what follows, we formulate what we believe to be three 'streams of research questions and propositions' that can promote a more dynamic perspective 
of psychological contracts to better approximate real employment relationships as experienced on a day-to-day, week-to-week, month-to-month basis, ultimately strengthening the impact of psychological contract research on organizational practice, and providing managers with handson knowledge on how to build stronger employment relationships with their employees.

The first question is 'What variables and processes operate during distinct periods of time or different psychological contract phases?', as outlined in the novel phase-based model of psychological contracts (Rousseau et al., 2018). For example, it would be interesting to explore whether changes in employee reactions co-vary with significant shifts in psychological contract phases, and whether these co-varying changes can be predicted based on characteristics of, for example, employees' breach perceptions. Minor breaches or breaches with low-intensity negative emotions are less likely to stimulate long-lasting change in employee reactions. That is, although there might be a minor increase in negative attitudinal or behavioral reactions following the breach, individuals will quickly settle back into their pre-breach attitudes or behaviors. In contrast, significant breaches associated with strong-intensity negative emotions are more likely to shift employees from the maintenance phase into the repair phase. Thus, we expect that employee reactions will co-vary with this shift from having a steady and reliable psychological contract into one that is characterized by low trust, distrust (see Coyle- Shapiro and Diehl, 2018), cynicism (see Griep \& Vantilborgh, 2018a), and intense negative emotions. Such reactions serve as the catalyst of long-lasting change in employee reactions. For example, there might be a sudden sharp increase in negative employee attitudes and behaviors, lasting for several weeks or months, making these employees more sensitive to future breaches and likely to increase their baseline levels of negative attitudes and behaviors. For instance, the negative effects of psychological contract breach on trust appear to be long-lasting, lending support to Ballinger and Rockmann's (2010) idea that negative anchoring events provide a frame of reference through which future events are interpreted. Empirical evidence suggests that breach in the previous employment generates mistrust that is carried over to the subsequent employer (e.g., Pugh, Skarlicki, \& Passell, 2003). Going a step further, in the case of dissolution of the psychological contract, employees fail to return to the maintenance phase and have a functional psychological contract to rely on. Instead they are likely to sustain their negative attitudes (e.g., distrust) or behaviors (e.g., counterproductive work behav-ior), ultimately eroding their relationship with their employer. 
The second research question is 'How does time influence the emergence of perceptions of psychological contract fulfillment, breach, and violation, and does the nature of the obligation play a role?' Although we have enough research evidence indicating that psychological contract breach occurs when an employee perceives a discrepancy between what the employer was obligated to provide and what was delivered (for metaanalyses see Bal et al., 2008; Zhao et al., 2007; see also Morrison \& Robinson, 1997), we have a poor understanding of factors that elicit perceptions of discrepancies. For example, the phase-based model of psychological contracts (Rousseau et al., 2018) suggests that the length of time it takes to fulfill particular obligations can impact the extent to which one may notice a discrepancy in one's psychological contract, and the length of time it takes to fulfill particular obligations may also impact the intensity of reactions following a perceived breach. We note that some obligations (e.g., receiving a promotion) take longer to fulfill than other obligations (e.g., receiving respectful treatment). Based on the work of Blount and Janicik (2001) people are known to establish 'reference points' for when particular outcomes should be realized based on societal norms and mutual agreements, and, when time delays exist in meeting temporal expectations, such as when obligations will be fulfilled, a variety of negative reactions ensue (e.g., anger, Blount \& Janicik, 2001; frustration, Amsel, 1992). Additionally, calls in the literature highlight the need for more research around the impact of unmet expectations in employee relationships (e.g., Nienaber, Romeike, Searle, \& Schewe, 2015). Further, if we consider the inherent temporal nature of proto- typical psychological contract types (relational and transactional; Rous- seau \& McLean Parks, 1993), we can try to identify timing expectations for the fulfillment of diverse relational and transactional obligations and test timing hypotheses concerning the onset of breach perceptions and the accompanying employee reactions. Specifically, relational psychological contracts are relationship-oriented, highly subjective, flexible, and long-lasting, whereas transactional psychological contracts are described as being economically focused, tangible, specific, static, and short-term in nature. Thus the onset of breach perceptions is potentially more likely and more frequent for transactional, as opposed to relational, psycho- logical contracts (although a cross-sectional study, Raja, Johns, \& Ntalianis, 2004, hints toward this argument). Given the long-term nature and subjectivity inherent in relational contracts, people are more likely to believe that relational obligations will be fulfilled at some point in the future and therefore be less likely to adjust their emotions, attitudes, or behaviors immediately following a deviation from such obligations (Rousseau, 1990). In contrast, the short-term focus and explicit nature of 
transactional obligations implies that deviations are more salient, leading to adjustments in emotions, attitudes, and behaviors in the immediate aftermath of a deviation from these obligations (Robinson, Kraatz, \& Rousseau, 1994).

Our last research question is 'What is the role of time in predicting recovery from psychological contract breach and does the nature of the obligation matter in overcoming violation?' In line with the theoretical tenets of the post-violation model (Tomprou et al., 2015), recovery from a severe instance of psychological contract breach (i.e., violation) occurs when the perceived discrepancy between the organization's obligation to provide a certain inducement and the extent to which the organization actually delivers that inducement is addressed and the organization takes steps to mitigate the employee's negative feelings that are associated with the violation. The post-violation model stipulates that the speed of violation resolution has implications for the type of psychological contract outcome (i.e., thriving, reactivation, impairment, succumbing) attainedswifter organizational responsiveness predicting shorter recov- ery times and more favorable employee outcomes. However, the exact length of this recovery process may depend on a number of different factors such as the type of obligation (i.e., relational versus transactional) breached and the importance individuals attach to the breached obligation (see Montes \& Irving, 2008). Recovery may be much slower and negative employee reactions could be more likely to linger for relational violations. Alternatively, and in direct contrast to the above, a trans- actional violation-owing to the fact that it is a core part of the psychological contract and a tangible obligation-could have a much more profound effect on the level of trust and/or trustworthiness employ- ees bestow upon their employer. As a consequence, employee reactions are likely to be more severe, and it might take multiple iterations to restore the damaged trust. Developing a better understanding of potential differences in recovery duration and lingering employee reactions across types of obligations can enable practitioners to better target, focus, and time the interventions they can implement to help restore the employee- employer relationship.

\section{Individual Differences in Perceptions of Time}

Subjective time experiences (labeled "temporal variables" by Sonnentag, 2012) are also associated with various time-related individual differences such as time perceptions and temporal depth (Shipp, Edwards, \& Lambert, 2009; Shipp \& Jansen, 2011). These subjective time percep- tions may influence different aspects of the psychological contract 
process, such as when breach is experienced, intensity of employee postbreach reactions, speed of recovery, and so on. Individuals may have different time perceptions which may affect their responses to psychological contract breach. Time is, as explained, not just the ticking of the clock, but also the product of human imagination, and therefore individual or collective imagination of time may form psychological contract perceptions and interpretations. For instance, a static time perspective may indicate that individuals refer to a specific episode (e.g., a breach event) to which they cling on, and refer any subsequent interaction with their organization. A repetitive time perspective may indicate cycles, and individuals may go through breach cycles over and over again, in line with the psychological contract phase model (Rousseau et al., 2018). An accumulative time perception may indicate that individuals believe that they build on past experiences of breach and fulfillment, which over time may lead to a breakdown of the psychological contract. Time perceptions related to incremental or evolutionary changes may indicate that individuals believe in either progress or dissolution of the psychological contract over time, and may act accordingly to fulfill their own beliefs concerning the impact of time on their relationships with the organization. Finally, individuals may also have more radical time perceptions, such as teleological, renewable, or projected time perceptions. Teleological time perceptions indicate that individuals believe that, over time, a certain end state will be reached, and that some act of revolution may be needed to achieve this. Renewable time perceptions refer to a belief where individuals renew relationships over time by taking a new start to their relationship with their employer. Finally, projected time perceptions are more utopian, and concern the belief of individuals that there is some mythical end point, a fantasized end state where the psychological contract over time reaches its optimum. All of these different time perceptions may be individual or shared across teams or organizations, and may determine the extent to which psychological contract percep- tions are formed and how people individually and collectively respond to psychological contract dynamics.

\section{SPOTLIGHT ON THE SOCIAL CONTEXT}

Psychological contract breach is a relatively common event in the workplace. The majority of employees have experienced a psychological contract breach in their career (Robinson \& Rousseau, 1994), and psychological contract breaches can occur at weekly (Conway \& Briner, 2002) or even daily (Griep \& Vantilborgh, 2018a) intervals. Thus it is 
important to understand when, why, and where psychological contract breaches emerge and shape interactions between the different parties involved (i.e., whether this is in the traditional 'vertical' employeremployee relationships or the more 'distributed' employee-other actor relationships), and how to mitigate or prevent their detrimental consequences. As it stands, we have a plethora of research on the antecedents and/or consequences of psychological contract breach (for meta-analyses see Bal et al., 2008; Zhao et al., 2007). In contrast, far less is known about how the social context influences the emergence of breach percep- tions and associated employee reactions (for two exceptions in this book see Chapter 8 by Akkermans, de Jong, de Jong, and Bal; Chapter 11 by Solinger; see also Ho, 2005; Morrison \& Robinson, 1997). This lack of contextualization is surprising because: 1) the experience of breach may depend on factors such as social norms, organizational/team/unit climate, organizational politics, and the nature of the relationship between the employee and the other actors involved in the contracting process; and 2) Rousseau and Fried (2001) have already argued that one important goal for psychological contract research to pursue is to broaden our contextual understanding of contracting by accounting for the roles of micro-, meso, and macro-level contexts. Despite the demonstrated importance of taking context seriously (O'Leary-Kelly, Henderson, Anand, \& Ashforth, 2014; Rousseau \& Fried, 2001) it remains understudied in the psycho- logical contract literature.

To better understand how (social) context influences the process of contracting, and when, why, and where perceptions of psychological contract breach or fulfillment emerge and shape interactions among employers, employees, and other actors, we need to consider how social context determines workplace interactions. The social context of the work environment, created through the frequent interactions we have with others at work, has the potential to satisfy our innate desire to belong and affiliate with others (Ryan \& Deci, 2000) and to form a social network of individuals we can rely on for social and emotional support. However, that context is not always supportive, and under certain circumstances, may actually hamper one's fundamental need to belong and affiliate with others (Ryan \& Deci, 2000). In the field of workplace bullying, Salin (2003) outlined how three key factors of social context-enabling structures, motivating structures, and precipitating processes-might enable negative events, such as perceptions of breach or violation, and might explain why they persist over time. We now describe how these three factors of social context connect to psychological contracts: 
- Enabling structures-such as the perceived power or status imbalance between employees and organizational agents, the high work demands placed upon both parties, or the lack of well-defined employment conditions-create a breeding ground, and the necessary conditions, for perceptions of psychological contract breach or violation to occur in the first place. Although a few studies have explored the role of such enabling structures in relation to the psychological contract (e.g., Vantilborgh, Bidee, Pepermans, Griep, \& Hofmans, 2016, who studied the role of work demands in relation to the emergence of psychological contract breach percep- tions; Sherman and Morley, 2016 also studied the effect of super- visors' ability to 'let go' of their personal psychological contract breach perceptions when managing their relationship with a sub- ordinate), there is still ground to be covered here. Interesting research avenues center around an array of questions such as: 'Do certain types of organizational, team, unit, professional, sectoral, regional, or national climate (e.g., characterized by self-interest, hostility, competitiveness, or collective silence) facilitate breach perceptions and cause employee reactions to linger, whereas other types of organizational, team, or unit climates (e.g., characterized by collectivism, shared responsibility, or problem-solving orien- tation) impede such perceptions and, if such perceptions do arise, do they foster quick recovery?' 'Are certain reward systems, such as bonus payments, more prone to the development of distributive injustice perceptions and thus to the emergence of perceptions of breach?' 'Are some supervisors or other organizational agents more inclined to break their obligations toward certain employees and, if so, which factors contribute to this inclination?'

- Motivating structures-such as competitive work environments, policies that reward goal achievement, or a neo-liberal vision of how work should be done and how employees fit within that visioncreate the 'reward' that is being associated with breaking one's obligations toward the other party in the mutual exchange relationship. Very few studies looked at the role of such motivating structures in relation to the psychological contract (for some exceptions see Chapter 7 by Bal and Hornung; Chapter 11 by Solinger; McDermott, Conway, Rousseau, \& Flood, 2013). Build- ing further on this raises a variety of interesting questions: 'What role does inequality, such as pay disparity, or competitive and neo-liberal organizational policies play in the experience of psycho- logical contract breach and violation and to what extent do these 
structures and policies influence employee reactions in the aftermath of breach or violation?' 'What role do these structures and policies play in the resolution process, and are employers, employees, and other parties involved in the psychological contract process more or less likely to attempt to restore the mutual exchange relationship in the face of, for example, reward structures and compensation systems that foster competition?'

- Precipitating processes-such as the implementation of austerity measures, lack of justice surrounding the implementation of new organizational policies or changes to existing policies, or any event that may threaten the status quo and shake the psychological contract from its maintenance phase into the repair phase-act as triggers of psychological contract breach or violation. This is probably the most well-researched key factor of social context in the psychological contract research, with examples ranging from understanding how organizational change implementation increases perceptions of psychological contract breach (Baillien, Griep, Vander Elst, \& De Witte, 2018; Pate, Martin, \& Staines, 2000) to understanding the influence of austerity and recession on perceptions of psychological contract breach (Conway, Kiefer, Hartley, \& Briner, 2014). Nevertheless, there are plenty of exciting avenues for future research: 'What actions on behalf of the organization, employee, or other agents in the mutual exchange relationship have the potential to mitigate the influence of these precipitating processes?' 'What is the role of society as a whole, if any, in the coming about and dealing with these precipitating processes?'

\section{SPOTLIGHT ON THE CHANGING NATURE OF WORK}

At the very core of psychological contract research lies the attempt to understand how individuals experience their employment relationship. However, the world of work changes constantly, including where, how, when, and why work is conducted. Several chapters speak to this changing nature of work when addressing topics such as voluntary work (see Chapter 6 by Kappelides and Jones), idiosyncratic deals (see Chapter 7 by Bal and Hornung), team or unit climate (see Chapter 8 by Akkermans, de Jong, de Jong, and Bal), and vulnerable workers and precarious employment conditions (see Chapter 10 by Tomprou and Bankins). However, management and organizational studies-including psychological contract studies-largely ignore these changes and their 
impact on the psychological contract in today's working environment (Barley, Bechky, \& Milliken, 2017).

Looking at where and when work is done, we note the uptake of more flexible work arrangements such as remote, virtual, and tele-work, distributed or virtual teams, and the advent and use of off-site communal share- or co-work spaces, all of which create a physical (and potential psychological) distance between an employee and his/her employer (Bjørn, Esbensen, Jensen, \& Matthiesen, 2014; Spinuzzi, 2012). Furthermore, unlike with traditional work conditions, employees now have greater interaction with a diverse range of other parties (e.g., clients, suppliers, consultants, temporary workers, interns, etc.) who are not part of the standard employee-employer relationship (Johns \& Gratton, 2013; Romeike, Nienaber, \& Schewe, 2016). As a consequence of more 'distributed' and horizontal forms of psychological contracts (Alcover, Rico, Turnley, \& Bolino, 2017; Ho, 2005) we, as researchers, need to pay more attention to the role of various agents in the contracting process within organizations, as well as to the importance of external and lateral relationships in the formation, maintenance, disruption, and repair of psychological contracts. Distributed psychological contracts not only can involve different kinds of obligations among the parties but also can alter notions of reciprocity given the diverse roles and ties the parties can have to each other (Alcover et al., 2017). Interesting avenues for research center around an array of questions: "Which actor is most salient in the psychological contract process: the traditional "vertical" employeremployee relationship or the more "distributed" employee-other actor relationship?' 'How do these multiple actors and distributed psychological contracts interact through processes of psychological contract breach and fulfillment over time?' 'How, if at all, can perceptions of psychological contract fulfillment in one of these distributed psychological contracts overcome the negative consequences commonly associated with perceptions of breach in the traditional "vertical" employeremployee relationship?' 'What are the implications of the implied precariousness of contemporary work for the psychological contracting process and how are such precarious employment conditions affecting vulnerable workers' ability to recover from perceptions of psychological contract breach?'

In addition to changes in where and when work gets done, how work gets done is changing, as we are witnessing the rise of the shared economy and 'gig' workers (e.g., Uber, Deliveroo, MTurk, etc.), wherein individuals 'contract out' their knowledge and skills for short periods of time to individual clients or businesses. Yet again, this implies a physical (and potentially emotional) gap between these 'gig' workers and their 
employers and place of work. While it may seem that the attraction of 'gig' working is the opportunity to earn an income quickly, emerging evidence suggests it may be wrong to assume that every psychological contract in this domain is transactional. Graham, Hjorth, and Lehdonvirta (2017) found that most 'gig' workers are looking for greater bargaining power when negotiating with clients, while also seeking to develop new skills. Seeking greater voice in the working relationship and opportunities for professional growth are typical content dimensions of a relational psychological contract. Relatedly, Petriglieri, Ashford, and Wrzesniewski (2018), in their study of work identities in the 'gig economy', found that many missed the social interaction and connections with colleagues typically evident in traditional employment. Moreover, technological advancements, such as machine learning and artificial intelligence (Bryn- jolfsson \& Mitchell, 2017), robots, teleconferencing, and wearable com- puting devices (Cascio \& Montealegre, 2016) are on the rise and have started to render the presence of human employees obsolete for certain aspects of jobs or jobs altogether. Overall, as Perrons (2003, p. 65) notes, these new technologies and emerging forms of work have allowed "the temporal and spatial boundaries of paid work to be extended" beyond our traditional understanding of an 'employer-employee' relationship. The increasing implementation of sophisticated technological advancement in the workplace also raises interesting questions regarding the conse- quences for the way employees experience their psychological contract: 'Does technological advancement alter the way employees perceive their interactions with other human agents of the organization and, if so, to what extent does a technological device become an active agent of the contracting process?' 'How does failure of technological advancements (e.g., malfunctioning, errors) influence the development of breach perceptions among employees, and do these breach perceptions trickle over onto human agents of the organization?' 'Does the implementation of technological advancements have the potential to better monitor obligations and respond to employee perceptions of breach or are these digital devices at the source of increased organizational control over employee behavior (e.g., geo-locating their employees at any point in time or sending "push" messages to their employees at any given moment of the day) and as a consequence at the source of increased perceptions of breach and pushing the boundaries of what is considered legal and ethical?'

Finally, the reasons why work is being done and why people go to work is also changing. In the past, Hendry and Jenkins (1997) observed a trend in the psychological contract literature in which organizations and employees were shifting the content of their obligations from more 
relational and loyalty-based to more transactional and performancecontingent obligations and promises. However, in the last decade, some scholars have seen this pendulum swing back toward more relationalbased, long-term, and loyalty-based arrangements. Probably the most obvious driver of this 'pendulum swing back' can be seen when looking at how organizations increasingly take their societal responsibilities more seriously through initiatives premised upon corporate social responsibil- ity (Preuss, Haunschild, \& Matten, 2009) in an attempt to contribute more meaningfully and broadly to society (van Berkel, Ingold, McGurk, Boselie, \& Bredgaard, 2017). In addition, we see an increase in the importance employees attach to work arrangements in which their organization is committed to, and can legitimately support, activities that benefit a third party such as a client, patient, or special interest group beyond the employee-organization dyad (Thompson \& Bunderson, 2003). These 'philosophical' shifts with respect to where organizations position themselves in society and the expectations that employees have toward their organization's commitment to this broader contribution to society have significant implications for psychological contract processes between an employee and an employer. Some interesting avenues for future research with respect to the why of work pertain to: 'Does this changing nature of work and increased focus on meaningful work cause organizations to develop, and employees to seek out, more socially and community-oriented, ideologically infused psychological contracts?' 'Does this focus on more socially and community-oriented, ideologically infused psychological contracts render perceptions of breach more severe and its accompanying negative employee reactions more long-lasting owing to the fact that an ideology is often related to different aspects of life and not solely focused on one's work identity?' 'How does the formation of more deeply engaging psychological contracts between an employer and its employees interact with the more traditional relational and transactional psychological contract types throughout the different phases of psychological contracting?' 'To what extent is the organization "riding the wave" of corporate social responsibility and using it as a window-dressing technique to attract employees looking for meaningful work, while not fulfilling its ideological mission?'

\section{CONCLUSION}

In sum, in this concluding chapter, a team of international psychological contract scholars has taken the time to pause the psychological contract field to look at its progress and identify new research streams to maintain 
and expand the impact psychological contract scholars can have upon scholarship and practice. We call attention to three key areas where we can mark a strong push for psychological contract scholars to answer questions related to: 1) the role of chronological and subjective time (dynamic approach toward psychological contracts); 2) the importance of social context; and 3) the changing nature of work and the numerous implications for the psychological contracting process. We look forward to seeing how the psychological contract field tackles these novel streams of research questions and its push to expand the field's theoretical, empirical, and methodological developments.

\section{REFERENCES}

Alcover, C. M., Rico, R., Turnley, W. H., \& Bolino, M. C. (2017). Understanding the changing nature of psychological contracts in 21st century organizations: A multiple- foci exchange relationships approach and proposed framework. Organizational Psychol- ogy Review, 7(1), 4-35. doi: 10.1177/2041386616628333

Amsel, A. (1992). Frustration theory: Many years later. Psychological Bulletin, 112(3), 396399. doi: 10.1037/0033-2909.112.3.396

Baillien, E., Griep, Y., Vander Elst, T., \& De Witte, H. (2018). The relationship between organisational change and being a perpetrator of workplace bullying: A three-wave longitudinal study. Work and Stress. Advance online publication. doi: 10.1080/ 02678373.2018.1496161

Bal, P. M., De Lange, A. H., Jansen, P. G. W., \& van der Velde, M. E. G. (2008). Psychological contract breach and job attitudes: A meta-analysis of age as a moderator. Journal of Vocational Behavior, 72(1), 143-158. doi: 0.1016/j.jvb.2007.10.005

Ballinger, G. A., \& Rockmann, K. W. (2010). Chutes versus ladders: Anchoring events and a punctuated-equilibrium perspective on social exchange relationships. Academy of Management Review, 35(3), 373-391. doi: 10.5465/AMR.2010.51141732

Barley, S. R., Bechky, B. A., \& Milliken, F. J. (2017). The changing nature of work: Careers, identities, and work lives in the 21st century. Academy of Management Discoveries, 3(2), 111-115. doi: 10.5465/amd.2017.0034

Beal, D. J., Weiss, H. M., Barros, E., \& MacDermid, S. M. (2005). An episodic process model of affective influences on performance. Journal of Applied Psychology, 90(6), 1054-1068. doi: 10.1037/0021-9010.91.5.1053

Bjørn, P., Esbensen, M., Jensen, R. E., \& Matthiesen, S. (2014). Does distance still matter? Revisiting the CSCW fundamentals on distributed collaboration. ACM Transactions on Computer-Human Interaction (TOCHI), 21(5), 27. doi: 10.1145/2670534

Blount, S., \& Janicik, G. A. (2001). When plans change: Examining how people evaluate timing changes in work organizations. Academy of Management Review, 26(4), 566- 585. doi: 10.5465/amr.2001.5393892

Bluedorn, A. C., \& Denhardt, R. B. (1988). Time and organizations. Journal of Manage- ment, 14(2), 299-320. doi: 10.1177/014920638801400209

Brynjolfsson, E., \& Mitchell, T. (2017). What can machine learning do? Workforce implications. Science, 358(6370), 1530-1534. doi: 10.1126/science.aap8062

Cascio, W. F., \& Montealegre, R. (2016). How technology is changing work and organizations. Annual Review of Organizational Psychology and Organizational Behav- ior, 3, 349-375. doi: 10.1146/annurev-orgpsych-041015-062352 
Conway, N., \& Briner, R. B. (2002). A daily diary study of affective responses to psychological contract breach and exceeded promises. Journal of Organizational Behavior, 23(3), 287302. doi: 10.1002/job.139

Conway, N., Kiefer, T., Hartley, J., \& Briner, R. B. (2014). Doing more with less? Employee reactions to psychological contract breach via target similarity or spillover during public sector organizational change. British Journal of Management, 25(4), 737-754. doi: 10.1111/1467-8551.12041

Coyle-Shapiro, J. A-M., \& Diehl, M.-R. (2018). Social exchange theory: Where is trust? In R. H. Searle, A.-M. I. Nienaber, \& S. B. Sitkin (Eds.), The Routledge companion to trust (pp. 197-217). New York, NY: Routledge.

Graham, M., Hjorth, I., \& Lehdonvirta, V.(2017). Digital labour and development: Impacts of global digital labour platforms and the gig economy on worker livelihoods. Transfer: European Review of Labour and Research, 23(2), 135-162. doi: 10.1177/ 1024258916687250

Griep, Y., \& Vantilborgh, T. (2018a). Let's get cynical about this! Recursive relationships between psychological contract breach and counterproductive work behavior. Journal of Occupational and Organizational Psychology, 91(2), 421-429. doi: 10.1111/joop.12201 Griep, Y., \& Vantilborgh, T. (2018b). Reciprocal effects of psychological contract breach on counterproductive and organizational citizenship behaviors: The role of time. Journal of Vocational Behavior, 104, 141-153. doi: 10.1016/j.jvb.2017.10.013

Hansen, D. S., \& Griep, Y. (2016). Organizational commitment and its related constructs: Psychological contracts. In J. Meyer (Ed.), Handbook of employee commitment (pp. 119-135). Cheltenham, UK and Northampton, MA, USA: Edward Elgar Publishing.

Hendry, C., \& Jenkins, R. (1997). Psychological contracts and new deals. Human Resource Management Journal, 7(1), 38-44. doi: 10.1111/j.1748-8583.1997.tb00272.x

Ho, V. T. (2005). Social influence on evaluations of psychological contract fulfillment. Academy of Management Review, 30(1), 113-128. doi: 10.5465/amr.2005.15281438 Johns,

T., \& Gratton, L. (2013). The third wave of virtual work. Harvard Business Review, 91(1), 66-73.

Kozlowski, S. W. J. (2009). Editorial. Journal of Applied Psychology, 94(1), 1-4.

McDermott, A. M., Conway, E., Rousseau, D. M., \& Flood, P. C. (2013). Promoting effective psychological contracts through leadership: The missing link between HR strategy and performance. Human Resource Management, 52(2), 289-310. doi: 10.1002/ hrm.21529

Mitchell, T. R., \& James, L. R. (2001). Building better theory: Time and the specification of when things happen. Academy of Management Review, 26(4), 530-547. doi: 10.5465/AMR.2001.5393889

Montes, S. D., \& Irving, P. G. (2008). Disentangling the effects of promised and delivered inducements: Relational and transactional contract elements and the mediating role of trust. Journal of Applied Psychology, 93(6), 1367-1381. doi: 10.1037/a0012851

Montes, S. D., \& Zweig, D. (2009). Do promises matter? An exploration of the role of promises in psychological contract breach. Journal of Applied Psychology, 94(5), 12431260. doi: $10.1037 / a 0015725$

Morrison, E. W., \& Robinson, S. L. (1997). When employees feel betrayed: A model of how psychological contract violation develops. Academy of Management Review, 2(1), 226256. doi: $10.2307 / 259230$

Ng, T. W. H., Feldman, D. C., and Lam, S. S. K. (2010). Psychological contract breaches, organizational commitment, and innovation-related behaviors: A latent growth modeling approach. Journal of Applied Psychology, 95(4), 744-751. doi: 10.1037/a0018804

Nienaber, A.-M., Romeike, P. D., Searle, R., \& Schewe, G. (2015). A qualitative meta-analysis of trust in supervisor-subordinate relationships. Journal of Managerial Psychology, 30(5), 507-534. doi: 10.1108/JMP-06-2013-0187 
Núñez, R., \& Cooperrider, K. (2013). The tangle of space and time in human cognition. Trends in Cognitive Sciences, 17(5), 220-229. doi: 10.1016/j.tics.2013.03.008

O'Leary-Kelly, A. M., Henderson, K. E., Anand, V., \& Ashforth, B. E. (2014). Psycho- logical contracts in a nontraditional industry: Exploring the implications for psycho- logical contract development. Group and Organization Management, 39(3), 326-360. doi: $10.1177 / 1059601114525851$

Pate, J., Martin, G., \& Staines, H. (2000). Exploring the relationship between psycho- logical contracts and organizational change: A process model and case study evidence. Strategic Change, 9(8), 481-493. doi: 10.1002/1099-1697(200012)9:8<481::AID- JSC513>3.0.CO;2G

Perrons, D. (2003). The new economy and the work-life balance: Conceptual explorations and a case study of new media. Gender, Work and Organization, 10(1), 65-93. doi: 10.1111/1468-0432.00004

Petriglieri, G., Ashford, S. J., \& Wrzesniewski, A. (2018). Agony and ecstasy in the gig economy: Cultivating holding environments for precarious and personalised work identities. Administrative Science Quarterly. Advance online publication. doi: 10.1177/ 0001839218759646

Preuss, L., Haunschild, A., \& Matten, D. (2009). The rise of CSR: Implications for HRM and employee representation. International Journal of Human Resource Management, 20(4), 953-973. doi: 10.1080/09585190902770893

Pugh, S. D., Skarlicki, D. P., \& Passell, B. S. (2003). After the fall: Layoff victims' trust and cynicism in re\{employment. Journal of Occupational and Organizational Psychol- ogy, 76(2), 201-212. doi: 10.1348/096317903765913704

Raja, U., Johns, G., \& Ntalianis, F. (2004). The impact of personality on psychological contracts. Academy of Management Journal, 47(3), 350-367. doi: 10.5465/20159586 Robinson, S. L., Kraatz, M. S., \& Rousseau, D. M. (1994). Changing obligations and the psychological contract: A longitudinal study. Academy of Management Journal, 37(1), 137-152. doi: $10.5465 / 256773$

Robinson, S. L., \& Rousseau, D. M. (1994). Violating the psychological contract: Not the exception but the norm. Journal of Organizational Behavior, 15(3), 245-259. doi: 10.1002/job.4030150306

Roe, R. A. (2008). Time in applied psychology: The study of 'what happens' rather than 'what is'. European Psychologist, 13(1), 37-52. doi: 10.1027/1016-9040.13.1.37

Romeike, P. D., Nienaber, A. M., \& Schewe, G. (2016). How differences in perceptions of own and team performance impact trust and job satisfaction in virtual teams. Human Performance, 29(4), 291-309. doi: 10.1080/08959285.2016.1165226

Rousseau, D. M. (1990). New hire perceptions of their own and their employer's obligations: A study of psychological contracts. Journal of Organizational Behavior, 11(5), 389-400. doi: $10.1002 /$ job.4030110506

Rousseau, D. M., \& Fried, Y. (2001). Location, location, location: Contextualizing organizational research. Journal of Organizational Behavior, 22(1), 1-13. doi: 10.1002/ job.78

Rousseau, D. M., Hansen, D. S., \& Tomprou, M. (2018). A dynamic phase model of psychological contract processes. Journal of Organizational Behavior. Advance online publication. doi: 10.1002/job.2284

Rousseau, D. M., \& McLean Parks, J. (1993). The contracts of individuals and organ- izations. Research in Organizational Behavior, 15, 1-43.

Ryan, R. M., \& Deci, E. L. (2000). Intrinsic and extrinsic motivations: Classic definitions and new directions. Contemporary Educational Psychology, 25(1), 54-67. doi: 10.1006/ ceps.1999.1020

Salin, D. (2003). Ways of explaining workplace bullying: A review of enabling, motivating and precipitating structures and processes in the work environment. Human Relations, 56(10), 1213-1232. doi: 10.1177/00187267035610003 
Sels, L., Janssens, M., \& Van den Brande, I. (2004). Assessing the nature of psychological contracts: A validation of six dimensions. Journal of Organizational Behavior, 25(4), 461488. doi: $10.1002 /$ job. 250

Sherman, U. P., \& Morley, M. J. (2015). On the formation of the psychological contract: A schema theory perspective. Group and Organization Management, 40(2), 160-192. doi: 10.1177/1059601115574944

Sherman, U. P., \& Morley, M. J. (2016). Organizational inputs to the formation of the expatriate psychological contract: Towards an episodic understanding. International Journal of Human Resource Management. Advance online publication. doi: 10.1080/ 09585192.2016 .1244103

Shipp, A. J., \& Cole, M. S. (2015). Time in individual-level organizational studies: What is it, how is it used, and why isn't it exploited more often? Annual Review of Organ- izational Psychology and Organizational Behavior, 2(1), 237-260. doi: 10.1146/ annurev-orgpsych032414-111245

Shipp, A. J., Edwards, J. R., \& Lambert, L. S. (2009). Conceptualization and measurement of temporal focus: The subjective experience of the past, present, and future. Organizational Behavior and Human Decision Processes, 110(1), 1-22. doi: 10.1016/ j.obhdp.2009.05.001

Shipp, A. J., \& Jansen, K. J. (2011). Reinterpreting time in fit theory: Crafting and recrafting narratives of fit in medias res. Academy of Management Review, 36(1), 76-101. doi: 10.5465/amr.2009.0077

Solinger, O. N., Hofmans, J., Bal, P. M., \& Jansen, P. G. (2016). Bouncing back from psychological contract breach: How commitment recovers over time. Journal of Organizational Behavior, 37(4), 494-514. doi: 10.1002/job.2047

Sonnentag, S. (2012). Time in organizational research: Catching up on a long neglected topic in order to improve theory. Organizational Psychology Review, 2(4), 361-368. doi: $10.1177 / 2041386612442079$

Spinuzzi, C. (2012). Working alone together: Coworking as emergent collaborative activity. Journal of Business and Technical Communication, 26(4), 399-441. doi: $10.1177 / 1050651912444070$

Thompson, J. A., \& Bunderson, J. S. (2003). Violations of principle: Ideological currency in the psychological contract. Academy of Management Review, 28(4), 571-586. doi: 10.5465/amr.2003.10899381

Tomprou, M., Rousseau, D. M., \& Hansen, S. D. (2015). The psychological contracts of violation victims: A post-violation model. Journal of Organizational Behavior, 36(4), 561 581. doi: 10.1002/job.1997

van Berkel, R., Ingold, J., McGurk, P., Boselie, P., \& Bredgaard, T. (2017). Editorial introduction: An introduction to employer engagement in the field of HRM: Blending social policy and HRM research in promoting vulnerable groups' labour market participation. Human Resource Management Journal, 27(4), 503-513. doi: 10.1111/ 1748-8583.12169

Vantilborgh, T., Bidee, J., Pepermans, R., Griep, Y., \& Hofmans, J. (2016). Antecedents of psychological contract breach: The role of job demands, job resources, and affect. PlosOne, 11(5), e0154696.

Zhao, H., Wayne, S. J., Glibkowski, B. C., \& Bravo, J. (2007). The impact of psycho- logical contract breach on work-related outcomes: A meta-analysis. Personnel Psychol- ogy, 60(3), 647-680. doi: 10.1111/j.1744-6570.2007.00087.x 